\title{
Risk factors and epidemiology of human T-lymphotropic virus types 1 and 2 in US blood donors
}

\author{
Farnaz Vahidnia ${ }^{*}$, Susan L Stramer ${ }^{2}$, Debra A Kessler ${ }^{3}$, David E Krysztof ${ }^{2}$, Roger Y Dodd ${ }^{2}$, Ed Notari ${ }^{2}$, \\ Simone Glynn ${ }^{4}$, Brian Custer ${ }^{1}$
}

From 17th International Conference on Human Retroviruses: HTLV and Related Viruses

Trois llets, Martinique. 18-21 June 2015

Blood donations in the US are routinely screened for markers of human T-lymphotropic virus (HTLV). Seroprevalence and risk factors associated with HTLV-1 and -2 infection from the US Retrovirus Epidemiology Donor Study (REDS-II) Transfusion-Transmitted Viral Infection (TTVI) Rate and Risk Factor Study are reported. Among 14,809,334 blood donations screened during 2011-2012, 516 HTLV confirmed seropositive cases were identified, with an overall prevalence of 3.5 infections per 1,0 donations (95\% CI: 3.2-3.8). A casecontrol study of risk factors from 90 donors with serology-confirmed HTLV-1 infection, 102 with HTLV-2 (cases), and 1,587 donors with false-positive results (controls) was conducted. Frequencies and adjusted odds ratios (AORs) from separate multivariable logistic regression analyses for HTLV-1 and -2 cases compared to controls are reported. Mean age was 48.0 (SD: 12.4), 52.3 (SD: 11.0) and 41.7 (SD: 15.7) years for HTLV-1, HTLV-2 cases and controls, respectively. Being a firsttime donor, older, non-white, non-Hispanic female were significant demographic factors associated with both infections. HTLV-1 cases were more likely than controls to be Black (AOR: 13.3, 95\% CI: 6.1-29.2), born outside of the US (AOR: 8.6, 95\% CI: 4.0-18.4), have migrated (family or self) from an endemic area (AOR: 1.8, 95\% CI: 1.2-2.7), report sex with an IDU (AOR: 10.9, 95\% CI: 3.633.4) or have multiple partners (AOR: 3.1, 95\% CI: 1.5-6.1). HTLV-2 cases were more likely to be Black (AOR: 15.4, 95\% CI: 6.9-34.3), Native Americans (AOR: 10.7, 95\% CI: 1.5-77.0), report sex with an IDU (AOR: 27.2, 95\% CI: 9.7-75.8) or have multiple partners (AOR: 2.9, 95\%

${ }^{1}$ Blood Systems Research Institute, San Francisco, CA, USA

Full list of author information is available at the end of the article
CI: 1.5-5.7). US blood donors with HTLV-1 or -2 infection present with the known risk factors. Migration from endemic areas is mainly associated with HTLV-1 infection, while HTLV-2 is associated with Native American donors. Sexual risk behavior and IDU continue to be risk factors for both viruses.

\section{Authors' details}

${ }^{1}$ Blood Systems Research Institute, San Francisco, CA, USA. ${ }^{2}$ American Red Cross, Rockville, MD, USA. ${ }^{3}$ New York Blood Center, New York, NY, USA.

${ }^{4}$ National Heart, Lung and Blood Institute, Bethesda, MD, USA.

Published: 28 August 2015

doi:10.1186/1742-4690-12-S1-P84

Cite this article as: Vahidnia et al:: Risk factors and epidemiology of human T-lymphotropic virus types 1 and 2 in US blood donors. Retrovirology 2015 12(Suppl 1):P84.

Submit your next manuscript to BioMed Central and take full advantage of:

- Convenient online submission

- Thorough peer review

- No space constraints or color figure charges

- Immediate publication on acceptance

- Inclusion in PubMed, CAS, Scopus and Google Scholar

- Research which is freely available for redistribution

Submit your manuscript at www.biomedcentral.com/submit
() Biomed Central 